\title{
Application of Inculturation Criteria in Studies on the Indigenous Nature of the Church in Nubia
}

Nubia, like Carthage and Cyrenaica, witnessed the birth, exceptional development and twilight of the [local] Church, and as noted by an outstanding expert on Eastern Christianity, Atiya S. Azis, these communities "after a period in which the faith and theological scholarship flourished beyond every expectation, simply vanished from the world altogether"2. Today, only archaeological and epigraphic sources recall their former vitality and splendor. Christians in Nubia, although they created their own religious culture, forms of expression of the liturgy and art, and had an impact on the development of theology and science, disappeared and fell into oblivion. At the same time, Christian centers were established in North-East Africa which are still viable today. Communities in Egypt and Ethiopia, despite numerous difficulties as well as internal and external problems, have survived and function with their ancient heritage and traditions still in use. African Christianity was born at the very beginning of the Church, but as history has shown, faith in the Triune God has not survived everywhere, despite its vitality and splendor ${ }^{3}$. Why did the Church in Nubia collapse and fall into oblivion? Can the answer to this question be its relationship to the local culture?

${ }^{1}$ Katarzyna Anna Mich is an archeologist and a theologist. She defended her doctoral dissertation entitled "The problem of the indigenousness of the Church in Nubia in context of archaeological research" at the Faculty of Theology of the University of Cardinal Stephan Wyszynski in 2019. She works as an archeologist at Banganarti in Sudan under the supervision of professor Bogdan Żurawski from the Polish Academy of Sciences in Warsaw, e-mail: catrine.mich@gmail. com. ORCID: 0000-0002-4170-1124.

2 A.S. Azis, History of Eastern Christianity, Notre Dame 1968, p.468.

${ }^{3}$ K.A. Mich, Problem zakorzenienia chrześcijaństwa w lokalnej kulturze Nubii a język liturgii Kościoła nubijskiego [in:] Sudan wojna, polityka, uchodźcy, ed. W. Cisło, J. Różański, M. Ząbek, Pelplin 2016, p. 75. 
Although the process of the Christianization of Nubia and the history of the Nubian kingdoms have been a subject of interest to many scholars, the scientific literature has so far lacked theological reflection on the actualization of the Church into the local culture of the Kingdoms of Nobadia, Makuria and Alwa. They arose on the ruins of the former Meroitic Empire in the Middle Nile Valley. Although the impact of local culture on the process of Christianization is recognizable in missiology studies, so far, no comprehensive and long-term studies have been conducted which would attempt to observe and assess the impact of individual elements of the inculturation process on local Nubian culture.

\section{Nubia Christiana. Outline of the history of the Nubian kingdoms}

North-East Africa has been called Nubia since Roman times ${ }^{4}$. It was the biblical land of Kush, which the ancient Egyptians called Ta-Seti - "Land of the Bow", from the weapons used by its inhabitants. In ancient times it was the area of the southern part of the Nile Valley, from the 1st to the 6th cataract, between Elephantine and Shendi. Today these are areas of Sudan, from the border with Egypt to Khartoum. Over the course of several millennia, the peoples of these territories have created a variety of cultures and kingdoms with power centers in Kerma, Napata and Meroe. The term Nubia is primarily of an ethnic-linguistic nature ${ }^{5}-$ during the European Middle Ages this area was inhabited by people calling themselves Nubians who spoke Nubian from the Nilo-Saharan family. The northern part of the region, between the 1st and 2nd cataracts, is called the Lower Nubia, while Upper Nubia is further south, from the 2nd to the 6th cataracts. The region developed along the valley of the Nile River, which was its main settlement axis. As in Egypt, cities and villages were established along the river, where there were fertile arable lands. Outside this zone, the area was typically desert, only in the southern part turning into semi-desert ${ }^{6}$. Thanks to access to the Red Sea, Nubia had the possibility of contact with the east: Arabia and Byzantium.

At the beginning of the 3rd century BC, the capital and royal necropolis of the ancient Kushite state, which had been located in Napata, was moved to Meroe. This event is a new chapter in the history of the Kingdom of Kush. It begins the Empire of Meroe period, which collapsed around 330 AD. Peter Shinnie traces

${ }^{4}$ W.Y Adams, Nubia: Corridor to Africa, Princeton 1977, pp. 13-64.

5 A. Łajtar, Literatura biblijna w Nubii chrześcijańskiej, „Scripta Biblica et Orientalia” 7-8 (2015-2016), pp. 123.

${ }^{6}$ M. Drzewiecki, Mighty Kingdoms and their Forts. The Role of Fortified Sites in the Fall of Meroe and Rise of Medieval Realms in Upper Nubia, Warsaw 2016, p. 8. 
the reasons for its fall to the influx of the Noba people ${ }^{7}$, and László Török to trade rivalry with $\mathrm{Aksum}^{8}$. Researchers know almost nothing about the era that followed the fall of Meroe. At the beginning of the 5th century, the Nubians of the Middle Nile Valley formed three separate kingdoms. Closest to Egypt, between the 1st and 3rd Cataracts, was Nobadia with the capital in Faras (old Nubian Pachoras). In the central part, between the 3rd and 6th Cataracts, along the great loop of the Blue Nile, Makuria was created, whose capital was Dongola (old Nubian Tungul). Alwa was the southernmost kingdom of Nubia, covering the area at the confluence of the Blue and White Nile, whose main center was the city of Soba'.

At the end of the 6th century, all three Nubian kingdoms were Christian, or at least their leaders officially professed this new faith. Nobadia was baptized, at the hands of missionaries from Egypt sent by Empress Theodora, in the Monophysite rite. Makuria, meanwhile, was baptized in the Chalcedon (Melkite) rite at the hands of missionaries sent from Constantinople by Emperor Justin II. Alwa was Christianized in Nobadia in the Monophysite rite. Christianization of the Nubian kingdoms had not only religious but also political consequences. In the 7th century, Nobadia and Makuria united ${ }^{10}$. The historic confirmation of the union is dated to 704, when King Merkurios unified the two kingdoms and subjugated the Church to the Monophysite Patriarchate in Alexandria. However, the Chalcedon rite seems to have survived in Nubia. From the end of the 7th century, in the area from the first to the fifth cataract, there was one kingdom - Makuria - and one Church, which formally belonged to the Coptic Patriarchate in Alexandria. A period of exceptional development and wealth lasted for several centuries, and the Church grew with the development of the state. Cities were expanded, magnificent churches were built, and monasteries of Byzantine splendor were founded ${ }^{11}$.

For several hundred years, Christianity in Nubia created an amazing culture that, without losing its African character, was developed in the form of Mediterranean cultures, showing strong Byzantine influences, especially in architecture and art, and documents were usually written in Greek. When the entire Christian world of the time was trembling before the progressive expansion of Islamic

${ }^{7}$ P.L. Shinnie, Meroe: A Civilization of the Sudan, London 1967.

${ }^{8}$ L. Török, Late Antique Nubia: History and Archaeology of the Neighbour of Egypt in $4^{\text {th }}-6^{\text {th }}$ c. AD, Budapest 1988.

${ }^{9}$ D.A. Welsby, Medieval Kingdoms of Nubia. Pagans, Christians and Muslims along the Middle Nile, London 2002, pp. 24-28.

${ }^{10}$ See W.Y. Adams, The United Kingdom of Makuria and Nobadia. A Medieval Anomaly [in:] Egypt and Africa. Nubian from Prehistory to Islam, ed. W. Davies, London 1991, pp. 257-263.

${ }^{11}$ K.A. Mich, Znaczenie światyni chrześcijańskiej w świetle osadnictwa w Makurii [in:] Sudan - archeologia i historia, eds. W. Cisło, J. Różański, M. Ząbek, Warsaw 2015, p. 56. 
Arabs, one of the Nubian kingdoms did the impossible - in two battles it defeated the invaders and signed a favorable peace treaty. After this period of exceptional development, between the 12th and 13th centuries, however, there was a mysterious turn in the history of the Nubian kingdoms - they began to decline. This was caused by both political and economic crisis. In 1317, the puppet ruler of Makuria changed the royal throne room into a mosque. This event marks a symbolic end to Christianity in Nubia. The united kingdom soon ceased to exist. Decades later, Makuria broke up into several small kingdoms ruled by Muslim rulers. Makuria's traditions were continued by the Christian kingdom located in the area of the second cataract, Dotawo, whose existence has been confirmed until the end of the $15^{\text {th }}$ century ${ }^{12}$. Christians in Nubia continued to exist for a long time in the Islamized society as after the fall of the Christian kingdoms, local groups were registered who identified with Christianity although they were deprived of the pastoral care of priests.

\section{Sources and methods}

Christianity enters a culture very often already having a rich tradition, its own identity, forms of expression such as art, architecture, literature, and above all a belief system, rites of passage. How this happens will determine the rootedness of the new religion in the local culture. The use of local cultural patterns (cultural code) will certainly help consolidate the new faith's reception by the local population. Incorporating local elements into liturgy and prayer services, art and architecture, and adapting them to the local means of expression causes Christianity to take root in new areas and gives the Church the opportunity to survive even in times of internal and external problems.

Research on the problem of the indigenousness of the Church in Nubia has been based primarily on sources from research conducted in Lower and Upper Nubia from the beginning of the 20th century up until 2019, on positions such as those of Faras, Qasr Ibrim, Meinarti, Abdallah Nirqi, Island of Sai, Dongola, Banganarti, Ghazali and many others (map. 1).

Archaeological sources, and epigraphic sources primarily from excavations, were the basis for the analyses. By contrast, external historical sources on Christianity in Nubia are very fragmentary. This Church did not enjoy the interest of Byzantine writers, as in the case of northern Africa. Accounts of Arab travelers and chroniclers were, until recently, almost the only source of information about

12 A. Łajtar, Późnochrześcijańska Nubia widziana przez pryzmat inskrypcji z Banganarti, „Studia Źródłoznawcze” 8 (2009), p. 79. 


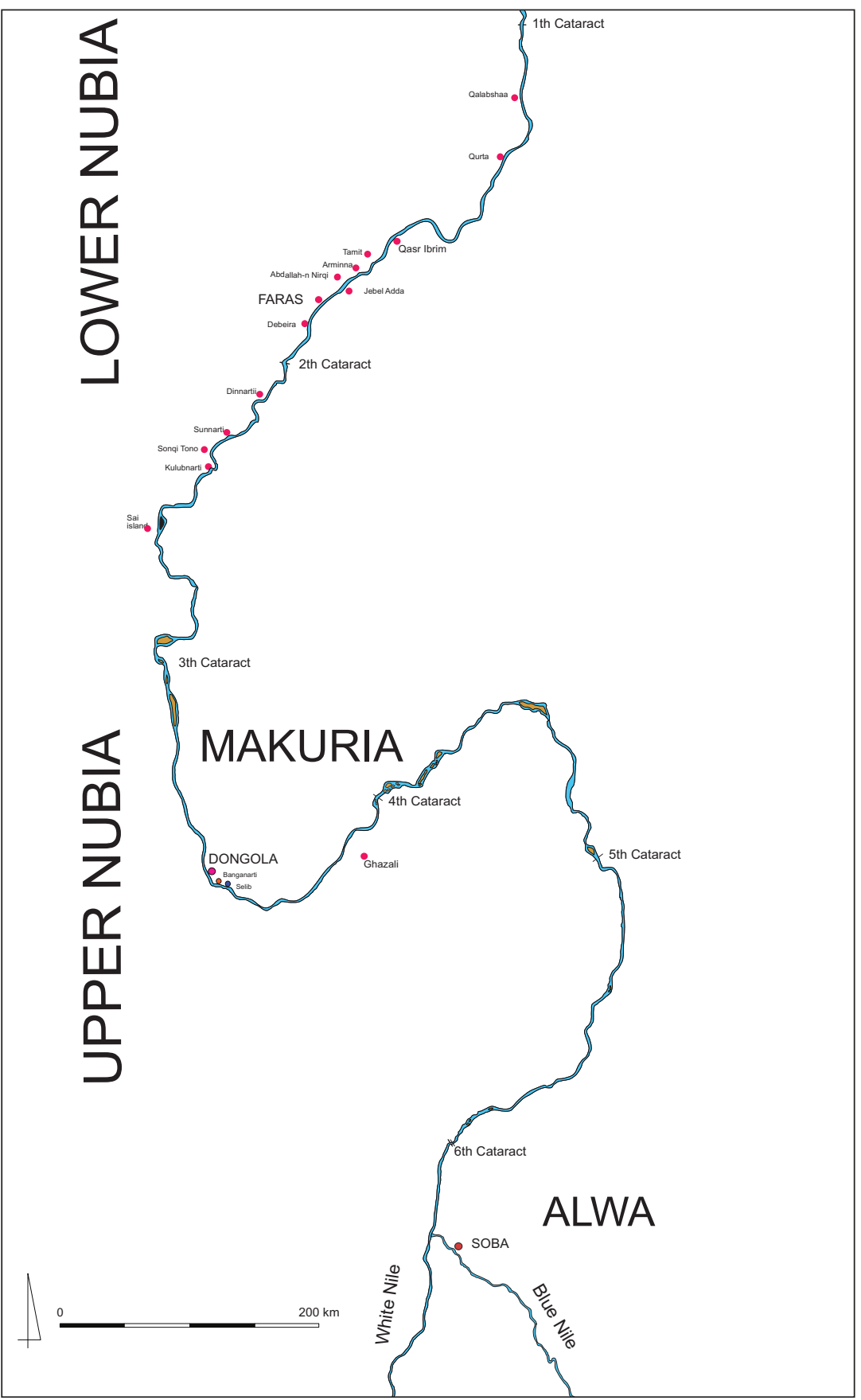

Map. 1:

Selected archaeological sites in Nubia, map digitally prepared by Katarzyna Mich 
Nubia, and were to a large extent uncertain. There are also a few sources from the Latin world, authors from all over Europe.

The author's analysis is based mainly on archaeological sources related to four main categories in which both continuity and cultural changes could be observed: monumental architecture, sacred and administrative; everyday architecture and the layout of homes; construction of graves and methods of burial; and manufacturing and handicrafts. It was also necessary to use verifications of the local literary culture, which were written in three languages: Greek, Coptic and Old Nubian. They come mainly from archaeological research. For this research, most important were religious texts, both of literary and paraliterary character (liturgical and private prayers, epitaphs, dedications of buildings for worship and elements of their decoration, inscriptions left by visitors in places of worship, etc.). The lack of literary sources regarding the functioning of both the Church and the Christian kingdoms of Nubia means that many of the conclusions regarding the Church's being actualized into the local Nubian culture are hypotheses based on archaeological research. In this research, the author moved away from typical historical presentation in favor of a conceptual and problematic approach and combined the method of analysis and criticism of archaeological and epigraphic sources with methods of examining processes and mechanisms of inculturation. The research is a theological reflection on the Church and its implementation in the local culture of Nubia.

\section{Application of inculturation criteria in research on the realization of the Church in Nubia}

The Church is universal and is directed by Christ's command to all peoples and languages, therefore it is to be open to any culture, ready to adopt it, deepen its identity and enrich it with its values, but also to convey it to the Person of Jesus Christ and all the richness of the Gospel. The awareness that every culture has true, good, and beautiful values, despite a lack of knowledge of Jesus Christ, should be the foundation of the missionary work of the $\mathrm{Church}^{13}$. The building up of a new Church in a specific culture should from its very beginning establish an integration with the individual, so that he may express himself as a Christian in the language of his community. Although culture has accompanied man since the beginning of his history, he has only recently turned to culture in Christian environments by introducing the category of culture to theology and Church teaching. Perceiving that the message of Jesus Christ is addressed to every person and

${ }^{13}$ L. Luzbetak, Kościól a kultury. Nowe perspektywy w antropologii misyjnej, trans. S. Tokarski, Warsaw 1998, pp. 84-86. 
every culture makes it possible to emphasize that the realization of the Church's mission is based on an encounter of dialogue and implementation between the Gospel and the culture ${ }^{14}$. The local culture is treated as the foundation upon which a new religion springs up, in this case Christianity. Christianity enters a culture very often already rich in tradition, with its own identity, modes of expression such as art, architecture, handicrafts, literature, and above all a well-formed belief system and rites of passage. The relationship of the new religion with the existing foundation bed is decisive for its later cultural identity. Therefore, there are strong links between the two spheres, which undergo modification over time: either the element of local culture might be more visible or vice versa: the Christian element completely rejects the element of local culture. Then there is no correlation of religion with the existing culture, which results in the new religion being completely foreign to the local population. There is a set of common cognitive elements to study the problem of religious identity, the process of inculturation of Christianity into local culture. While researchers conclude that the relationship of religion with local culture is very important for understanding the processes associated with a change of religion, which is a breakthrough event for a given culture, many nubiologists and Church historians marginalize the importance of local culture, seeing Christianity in Nubia as a one-sided process and not a mutual relationship of religion and culture, as does Richter in his publication Studien zur Christianisierung Nubiens from $2002^{15}$.

It is well-known that the concept of inculturation has undergone much research, being developed and refined over the past 40 years. In the broad spectrum of literature on this problem, the detailed study of Jarosław Różański deserves attention regarding the inculturation of the Church into the Gidar society of North Cameroon $^{16}$. Although it concerns society not comparable to the Nubians, it collects and organizes all the criteria for inculturation of the Church, giving tools to conduct analyses of other communities. The actualization of the Church in Nubia was realized in a specific community of the people of God as well as in its administrative structures and local hierarchy. It was brought about through the implementation of the sanctifying, prophetic and teaching missions, which are accomplished through the proclamation of the Gospel, the celebration of sacraments, funeral rites, and the teaching of prayer practices. Due to a lack of adequate resources, the Church's prophetic task was omitted. The Church, as archaeological research shows, also contributed to the life of the society and to the development of material culture of the inhabitants of the Middle Nile Valley.

${ }^{14}$ A. Pietrzak, Modele ewangelizacji kultur i inkulturacji wiary w teologii latynoamerykańskiej, Lublin 2013, p. 16.

${ }^{15}$ S.G. Richter, Studien zur Christianisierung Nubiens, Wiesbaden 2002.

16 J. Różański, Inkulturacja Kościoła wśród ludów środkowego Sudanu, Poznań 2004. 


\section{a. Inculturation criteria in creating the structure of the Church in Nubia}

Having its own Church structures is one of the requirements for the inculturation of Christianity into a given local culture. The creation of an archdiocese and associated dioceses is currently considered as the expression of a local Church's self-reliance within a given socio-cultural area (in practice, most often in the structure of a given country $)^{17}$. The creation of a Church structure has been a very important element in the process of adapting Christianity in new areas. While faith in the new God was initially imparted to the king and those around him, it eventually reached the furthest corners of the Nubian kingdoms. To carry out the process of evangelization and confirm the faith in Jesus Christ, it was important to create a well-functioning Church administration in Nubia, based on subdivisions - metropolitan archdioceses, auxiliary bishoprics, and parishes. Such a system of divisions guaranteed efficient management of pastoral activity and administration of the land belonging to the Church received from royal foundations.

It is known that there were at least seven dioceses in Nubia, including two archdioceses - Pachoros and Dongola, which constituted the core of the Church's organizational structure ${ }^{18}$. The latest research shows that this was based on the East Roman model ${ }^{19}$. It must have been established before the unification of the two kingdoms, because it reflected the system of organization of the kingdoms before they merged. We currently know little about the organization of dioceses or their importance in the structure of the kingdom or for Nubian society. Unfortunately, documents and correspondence among the two patriarchates and the other dioceses have been lost or destroyed. Relations of the Nubian Church with the two Patriarchates of Alexandria are known only from individual Egyptian sources, which show that the Church in Nubia fell within the sphere of influence of the Coptic Patriarchate of Alexandria for much longer than it was under Byzantine sovereignty.

From the 8th century, as Tadeusz Gołgowski notes, connections between the Nubian Church and the Coptic Church were strengthened because the Alexandrian Patriarchate was gaining influence over the Nubian Church hierarchy. The question of whether Nubia was entirely under the jurisdiction of the Alexandrian Patriarch or whether it had autonomy in the field of canon law and the organization of Church life is at this time unclear ${ }^{20}$. Perhaps Nubia, like Ethiopia, was

17 Ibidem, p. 239.

18 R. Seignobos, Les évêchés nubiens: nouveaux témoignages. La source de la liste de Vansleb et deux autres textes méconnus, in: Nubian Voices II: New Texts and Studies on Christian Nubian Culture, eds. A. Łajtar, G. Ochała, J. van der Vliet, Warsaw 2015, pp. 151-229.

19 M. Costalunga, L'organizzazzione in province e regioni ecclesiastiche, "Iius Canonicus" 22 (1982), p. 750 .

20 T. Gołgowski, Liturgia nubijska i problem jej rekonstrukcji, „Saecullum Christianum” 14 (2007) 1, p. 47. 
only nominally subject to Alexandrian Patriarchate ${ }^{21}$. So far, the only evidence of the synodality of the Church in Nubia has been an inscription commemorating a provincial synod in Dongola. An analysis of the Church structure of Nubia, however, shows strong local accents. The episcopal sees were located in the most important centers of the united kingdoms of Makuria and Nobadia. The bishops and clergy, apart from the first bishops who came to Nubia to organize the Church and the liturgy, came from local communities. The large number of churches suggest that there was an adequate number of clergy capable of serving so many places of worship. Perhaps the approach of the Church in Nubia was similar to that of Ethiopia ${ }^{22}$.

The strong dominance of the local Church by the royal authorities meant that it was dependent on the socio-economic situation of the state ${ }^{23}$. The welfare of the state was the welfare of the Church. A crisis of the state was also a crisis of the Church. The fall of the Christian rulers of Makuria was followed by the disappearance of church structures in Nubia ${ }^{24}$. The Coptic Church, which was occupied with its own problems, was unable to exercise direct pastoral care over the Nubian Church, which was in isolation ${ }^{25}$. It should be noted that Christians in Nubia resisted Islamization for a long time; after the collapse of the kingdoms, local groups were still being registered which identified themselves with Christianity, despite the lack of pastoral care.

\section{b. Inculturation criteria in gathering the People of God}

An assemblage of the People of God a Church represented by an adequate number of faithful, local clergy, monastic life, lay apostolic commitment is a necessary requirement for the development of Christian inculturation. The Church addresses the Gospel to the whole community, which should respond to the message preached to it. Without this active response of commitment to the Church, the creation of monastic life forms, and the establishment of local clergy, there is no mutual relationship between religion and culture ${ }^{26}$.

${ }^{21}$ See C.D.G. Müller, Grundzüge der Frommigkeit der nubische Kirche [in:] Études nubiennes. Colloque de Chantilly, 2-6 juillet 1975, eds. W.Y. Adams, P. Červíček, J. Leclant, Cairo 1978, pp. 209-224.

${ }^{22}$ Cf. E. Haberland, Feste im Kirchenjahr des Christlichen Äthiopiens, "Zeitschrift für Kulturaustausch" 1 (1973), pp. 56-58.

${ }^{23}$ C. Ballin, The Christian community in Sudan in its Islamic context with special attention given to the era of the Mahdist Revelution (1881-1898), Roma 2007, p. 38.

${ }^{24}$ Cf. J. Cuoq, Islamisation de la Nubie chrétienne: VII ${ }^{e}-X V I^{e}$ siècle, Paris 1986.

25 A.S. Azis, History of Eastern Christianity, p. 427.

${ }^{26}$ J. Różański, Inkulturacja Kościoła wśród ludów środkowego Sudanu, p. 164. 
The church in Nubia was able to create a local character. There being a sufficient number of the faithful, it was possible to give it Nubian features, although it seems that Christianity was adopted primarily by the elite of Makuria. The extent to which the Gospel penetrated the lowest social strata is now debatable. The settlement in Nubia has been very poorly researched, which makes it impossible not only to create a detailed picture of ordinary Nubians, but more importantly in the present analysis, also to attempt to answer the question of how faith in Jesus Christ was present in the lives of village residents, farmers and shepherds. Many scholars describe Christianity in Nubia as a religion of kings and aristocrats, suggesting that the Gospel did not sufficiently penetrate the lowest social strata ${ }^{27}$.

Names occupy an important place in all cultures and religions of the world. They are an element of the identity, culture and identification of man. They are very important because they show that on the cultural level Christianity has been integrated to some extent into the local culture. Sources for research into the onomastics and anthroponymy of Nubian society names are epitaphs, pilgrim inscriptions from Banganarti and documents from the archives of Qasr Ibrim. Inscriptions from the "Upper Church" in Banganarti, developed as edicio principe by Adam Łajtar, are of particular importance for the study of names used in Nubia during the 13th-14th centuries ${ }^{28}$. Researchers note that in the Banganarti inscriptions there are usually Nubian names, more rarely Greek-Nubian, in which the Greek root has a Nubian ending (most often -ou, -a or -i) or is associated with a Nubian word. Purely Greek names, including names of biblical origin, are relatively rare. It should be emphasized that Nubian personal names appearing in the Banganarti inscriptions were mostly authenticated for the first time. Only a few of them find parallels in the rich onomastic material provided by Old Nubian documents from Qasr Ibrim in Lower Nubia, which come from about the same period as the inscriptions from Banganarti ${ }^{29}$. An analysis of the names used in Nubia during the late Christian period shows that Nubian names clearly dominated. Greek names appear to be much more often verified in Lower Nubia. An interesting phenomenon that was important for the Church taking root in the local culture was the emergence of Nubian names associated with a Christian element. The most important seem to be those related to the name of Jesus Christ. The name Jesus (in Old Nubian Isou or Isou Christou) appears as a root of Nubian names, such as Iesousinoukout, Iesousnoukout, Iesousphoros. The first two probably mean Servant of Jesus, while the last may mean Jesus-Bearer. A popular

${ }^{27}$ C. Ballin, The Christian community in Sudan in its Islamic context with special attention given to the era of the Mahdist Revelution (1881-1898), p. 38.

28 A. Lajtar, A Late Christian Pilgrimage Centre in Nubia. The Evidence of Wall Inscriptions in the Upper Church at Banganarti, Leuven 2020.

29 Łajtar A., Późnochrześcijańska Nubia widziana przez pryzmat inskrypcji z Banganarti, pp. 89-90. 
root was also the name Maria - Mariame, Mariata, Marianos, Mariankouda. A theophoric name was Tillinminne, which evolved from the Old Nubian word Tilli, meaning $\operatorname{God}^{30}$. Associations with the names of saints and archangels - like Raphaelophorou - were also popular. Although Greek names (especially biblical and saintly) were widely used in Nubia, in the 12th-14th centuries, Nubian cultural identity strongly dominated.

The local clergy certainly favored giving a native character to Christianity in Nubia. It is believed that the clergy in Nubia came from the local community with few exceptions. However, we cannot say anything about their formation and education and preparation for the service of God. To conduct the liturgy, the priests had to at least read Greek, but were they able to explain theology and the Word to the people? It seems that the clergy of the Church there constituted a significant percentage of the community, as evidenced by the multitude of degrees and titles attested to in Nubia. Another important manifestation of the integration of Christianity into local culture was the emergence of monastic life. All kinds of centers in Nubia enjoyed considerable popularity, and although they were based on Byzantine and Egyptian models, they acquired a local color. However, they did not produce specific monastic literature, which was known even in Egypt, so reconstruction of the life of monks is based primarily on archaeological sources ${ }^{31}$.

Another important aspect is the attempt to define the involvement of lay people in the Church. The involvement of the entire People of God is necessary for a real implanting of the Church into local culture. The role of lay members of the Church is fundamental to the maturity of the local community. Although at present archaeological sources do not make it possible to determine the total body of secular tasks in the Church community or the laity's formation, certain areas can be designated in which lay people in Nubia could have been active. However, their degree and scope have remained unknown so far, especially as to the work of evangelization or forms of group apostolate, if any. So far, a double image has been captured from research on the layman in Nubia rich church patrons and funders of artwork, and pilgrims seeking healing or direct contact with the sacred. In Nubia, both men and women could be the rightful owners or patrons of churches and monasteries. This property could be transferred by will or established by a foundation ${ }^{32}$. Examples of church ownership by lay people come from the 11 th and 12 th centuries. This is undoubtedly a testimony to the high status and

${ }^{30}$ R. Werner, Das Christentum in Nubien: Geschichte und Gestalt einer afrikanischen Kirche, Münster 2013, pp. 354, 372, 403-404.

${ }^{31}$ See A. Obłuski, The Monasteries and Monks of Nubia, trans. D. Dzierzbicka, Warsaw 2019.

${ }^{32}$ R. Werner, Das Christentum in Nubien: Geschichte und Gestalt einer afrikanischen Kirche, p. 345 . 
development of consciousness among Christians ${ }^{33}$. Private foundations explain why some estates had several shrines, far too many in relation to the estimated population, which seems to be a cultural phenomenon of Nubian Christianity.

The growing role of private patrons and founders, both clergy and laity, since the 10th century has been noted; this contributed to the development of artwork through a greater variety of forms and themes. The appearance of kings and high dignitaries (laity and clergy) testify to their commitment to the development of painting in churches and monasteries. So far, images have been discovered in Faras, Dongola, Abdallah Nirqi, Tamit, Sonqi Tino and Banganarti. The founders presented themselves in the company of saintly patrons in fairly confidential relations with saints and archangels embracing them by the shoulders, shading them with their wings, putting their hands on their shoulders. In churches in smaller centers, meanwhile, images of representatives of the lower social classes have been preserved who, thanks to their material support of these shrines, obtained the right to place their own portraits on the walls. These foundations are testimony to the individual's aspiration to stand out from the crowd and mark his identity. Offering the work to God, of which the presentation of the donor is a part, was also an expression of faith in the effectiveness of the intercession of the saints. We see them as the founders of churches and works of art, which concerned only the richest. In this way they expressed concern for the good of the Church and believed that by this means they would secure a place in heaven.

The beginnings of pilgrimage in Nubia date back to pre-Christian times, when the rulers of Meroe, and then the emerging Nubian kingdoms, made pilgrimages to the Sanctuary of Isis on the island of Philae in Egypt ${ }^{34}$. The tradition of pilgrimage was also strong during the times of the Christian kingdoms; however, its exact reconstruction is hampered by lack of written sources relevant to the study of folk religiosity and the tradition of pilgrimage sites. This practice is attested to both among the kings of Makuria and high state officials, and also among local elites. Pilgrimage to places particularly marked by holiness was a form of religiosity very popular among the Nubians. They made pilgrimages not only to local centers, like Banganarti (center of devotion to the Archangel Raphael), Selib (center of devotion to Saint Menas), but there are also testimonies about their stays in Constantinople, in the Holy Land, in Santiago de Compostela, and most likely also in Rome ${ }^{35}$.

${ }^{33}$ A. Łajtar, J. van der Vliet, Rich Ladies of Meinarti and their Churches. With an appended list of sources from Christian Nubia containing the expression "having the Church of so-and-so", "The Journal of Juristic Papyrology" 28 (1998), pp. 50-53.

34 J.H.F. Dijkstra, Philae and the End of Ancient Egyptian Religion. A Region Study of Religious Transformation (298-642 CE), Leuven 2008, pp. 125-171.

${ }^{35}$ R. Werner, Das Christentum in Nubien: Geschichte und Gestalt einer afrikanischen Kirche, p. 323. 
Reconstruction of the significance of the family in Nubian society, which stands at the beginning of the creation of the local Church and its taking root in the local culture, is impossible due to lack of adequate sources. It seems that social issues, such as the Christian upbringing of children or family life, are impossible to reproduce due to a lack of literature on this topic, even homiletic literature (in which preachers would raise topics related to social life). A separate issue, also very difficult to reconstruct, is potential groups of Christians carrying out specific charisms of service in the community or specific social, prayer, apostolic, promotion of justice, or care for the poor charisms.

An equally important element affecting the cultural identity of Christianity is the cult of the saints. Despite only rudimentary sources, we can draw some general conclusions about both their veneration itself and their canon in Nubia. In the light of the current state of sources, we can attempt to reconstruct the development of the canon in Lower Nubia, since most of them have been authenticated in this area. Only a few saints are known from Upper Nubia. Nubia accepted faith in Christ at a time when all the basic models of holiness for Christianity had already been formed. The formation of the canon recognizes at least three different traditions associated with the importation of saints to Nubia. The Nubians received various saints whose cult was widespread in the East and adapted them to their needs. Although most of the saints reached Nubia through Egypt, a strong influence from the Byzantine, Palestinian and Antiochian traditions can also be distinguished. Moreover, there are significant differences between liturgical and folk worship. This may be due to the availability to the faithful, especially of iconographic representations, particularly of saintly warriors, for private devotion. However, the saints mentioned in the liturgical sources are not witnessed to anywhere else. It is also noted that some saints have penetrated strongly into popular piety. Furthermore, the cult of local saints is important for understanding the process of integrating holiness with local culture. So far, one such saint has been confirmed with absolute certainty, and in the case of several others there is a presumption of their being venerated. However, the history of the Church in Nubia is several hundred years old, and the existence of only a single local saint, Anna of Dongola ${ }^{36}$, may indicate that the idea of implementing models of sanctity in the everyday life of Nubians was not popular. It also seems that the saints in Nubia were understood only as intermediaries between man and God and were made use of for obtaining needed favors.

${ }^{36}$ A. Lajtar, Anna, the first Nubian Saint Know to us?, "Bulletin de la Société d'archéologie copte" 56 (2017), pp. 91-110. 


\section{c. Inculturation criteria in fulfilling the teaching office of the Church}

The proclamation of the Gospel to all nations is the duty of the Church established by Jesus Christ. Carrying out this teaching office should consist in safeguarding revealed truth, careful study, and faithful preaching through the assistance of the Holy Spirit. Living and proclaiming the Gospel also inspires Christians to gather into one, thus creating various forms of dialogue with other religions. It teaches respect for religious and cultural diversity, hence leads to interreligious dialogue. Finally, by its very nature, it stimulates Christians to share the Gospel with those who do not yet know Christ, within their surroundings as well as beyond their own environment, thus enkindling a missionary spirit in the local $\mathrm{Church}^{37}$.

To lead to conversion, doctrine and theological knowledge must have recourse to the local conceptual framework and way of reasoning. An analysis of the local theology of the Church in Nubia, in light of available sources, shows that it was based primarily on a syncretic combination of orthodox teaching with elements of magic, local beliefs and apocrypha. The rich spectrum of Christian literature originating mainly from Coptic Egypt and only sparse Nubian works shows that the Church in Nubia was based on foreign material. It was almost completely dependent on the influence of theological ideas from outside and did not undertake deeper reflection on the truths of Faith being taught ${ }^{38}$. Magic and apocrypha, especially, were present in the lives of Christians there. Apocryphal motifs were intermingled with orthodoxy, which created a specific feature of Nubian Christianity. We do not know anything about institutions that would have been responsible for the purity of Christian teaching. Looking at the development of Nubian theology, we come to the conclusion that there was in that Church a total arbitrariness in how it was laid out, and most likely every bishop had the opportunity to interpret it freely. Most likely, the local clergy was not educated in theology, either. We do not know of any theological school in Nubia nor of local theologians producing theological treatises. The question of whether the clergy could have been educated in theological schools in Egypt or in Byzantium now requires thorough examination.

God, in the understanding of Nubian Christians, was someone very distant and inaccessible, like the emperor. This concept resulted in the development of the idea of mediation between God and man. Archangels, the Mother of God, and saints played the role of intermediaries. A characteristic feature of Nubian Christianity was the understanding of the cross of Christ as a sign of the Parusia, where it had central significance as a tool of judgment. The cross in Nubia was

\footnotetext{
37 J. Różański, Inkulturacja Kościoła wśród ludów środkowego Sudanu, p. 267.

${ }^{38}$ A. Łajtar, Literatura biblijna w Nubii chrześcijańskiej, pp. 130-134.
} 
an attribute of the glory, power, and victory of Christ, not of His humiliation, powerlessness and shame ${ }^{39}$. One of the elements of mature Christianity is the translation of the Holy Bible into the local language and this element was present in Nubia. In the light of available sources, we know that translations of the New Testament into Old Nubian were part of the Liturgy of the Word in the local churches ${ }^{40}$. However, it seems that the Scriptures were read in Nubia without explanations and references to the new cultural context, which made them difficult to understand for the Christians there.

The strongly ethnocentric nature of Christianity in Nubia meant that the Church did not undertake active missionary activity, especially among the emerging threats at the borders of the kingdom caused by the emergence of new tribal groups, which later became Islamized, as well as the more local peoples. Including them within the circle of the Christian culture of Nubia would certainly have changed the balance of power and made it possible to control border areas. Certainly, this was one of the main reasons for the fall of Christianity.

\section{d. Inculturation criteria in the implementation of the Church's sanctifying office}

The implementation of the sanctifying mission is one of the basic tasks of the Church. It is implemented in a special way in the celebration of the holy liturgy, which is the exercise of the priestly office of Jesus Christ; and in this, through visible signs, it is revealed and in a special way sanctifies each person. The Church fulfills the task of sanctification by administering the sacraments and establishing holy places and times. The task of sanctifying is carried out in a specific period of history, in a specific place and in a particular culture. It is a kind of constant call for a renewed incarnation of Christ, modeled on the economy of salvation ${ }^{41}$. There is not much to say about the administration of the sacraments in Nubia, except for the Eucharist and baptism (and probably confirmation, which according to Eastern tradition took place together with baptism), therefore the other sacraments: the sacrament of penance and reconciliation, marriage, holy orders, and the anointing of the sick, have been omitted from this study. Other Christian practices, such as funerals, blessings, or the dedication of churches, altars, vestments and liturgical utensils, fall into the category of rites and sacramentals. It is worth noting, however, that the Eastern Fathers were not interested in the number

${ }^{39}$ R. Werner, Das Christentum in Nubien: Geschichte und Gestalt einer afrikanischen Kirche, p. 365 .

${ }^{40}$ See G. Ochała, The Nubian liturgical calendar. The evidence of the Nubian lectionaries, "Le Muséon" 128 (2015), pp. 1-48.

${ }^{41}$ J. Różański, Inkulturacja Kościoła wśród ludów środkowego Sudanu, p. 343. 
of mysteries, nor did they set themselves the task of counting them ${ }^{42}$. The most important of the rites for understanding the question of the native character of the local Church is the Christian funeral.

An analysis of inculturation criteria in carrying out the sanctifying office shows that throughout the Christian era the Nubians did not simply slavishly copy the customs and liturgical practices originating in Eastern Christianity but adopted them according to their own needs. This is especially evident in the selection of a northern pastophorion - prothesis, the iconographic program, as well as in the adaptation of liturgical equipment and vessels, and also the liturgical calendar. One could even say that the liturgy of the Church in Nubia had its own native character. It appears that local liturgical customs were also created for the celebration of baptism. The Church in Nubia was probably not strictly controlled by any Patriarchate, and perhaps, as T. Gołgowski notes, it maintained at least partial independence in the field of canon law and the organization of Church life ${ }^{43}$.

However, the use of the Greek language in the liturgy made it incomprehensible to the Nubian laity, who turned to alternative forms of worship. Poor knowledge of the Holy Scriptures and Christian doctrine meant that orthodoxy was replaced by apocryphal literature with miracle stories, and the cult of saints, especially archangels, overshadowed Christ as the Only Mediator of Salvation. Also, changes in church architecture suggest that the liturgical role of the laity diminished over time $^{44}$. It is noted that the space of the naos intended for the faithful was significantly reduced, as in the cathedral of Faras, and the area of the sanctuary was increasingly concealed ${ }^{45}$. Some historians attribute the final disappearance of Nubian Christianity to a lack of full adaptation to local culture. The faces of Christ, His Mother, and saints have always been painted white in Nubian iconography, in contrast to Nubians, which certainly influenced the adaptation of Christianity into the local culture. It is noteworthy that in neighboring Ethiopia, where Christianity was also isolated, there was no such color distinction ${ }^{46}$. And it is difficult to confirm whether fasting, penance and pilgrimage practices associated with prayer formulas and an allegorical understanding of cult rites gave a sense of satisfaction for sins and the hope of gaining eternal life ${ }^{47}$, as no written sources have survived. A characteristic element of Nubian piety was devotion to archangels and angels, heavenly

42 See A. Baczyński, Zarys nauki o sakramentach w Kościele prawosławnym i rzymskokatolickim, „Elpis” 19 (2017), pp. 169-179.

43 T. Gołgowski, Liturgia nubijska i problem jej rekonstrukcji, p. 47.

44 J. Iliffe, Africans: The History of a Continent, Cambridge 1995, p. 42.

45 W. Godlewski, Pachoras. The Cathedrals of Aetios, Paulos and Petros. The Architecture, Warsaw 2006, p. 59.

46 J. Iliffe, Africans: The History of a Continent, p. 42.

47 S. Araszczuk, Język i formy pobożności ludowej, „Seminare. Poszukiwania naukowe” 20 (2004), p. 169. 
mediators between the faithful and God. They had a very important function in Nubian popular piety, because they were close to the people, who could contact them directly. Many of the Christian elements of popular piety are still present in the lives of modern Nubians practicing Islam. Christian traditions are still visible in their customs and practices of the liturgical seasons, holy days, and everyday life. This is due to the fact that Christianity went deep into local culture, and relics of it are still present, although much less so than at the beginning of the 20th century.

An analysis of funeral practices in Nubia has shown that changes in funeral customs under the influence of Christianity are apparent primarily from archaeological sources. During the Christian period, the position of the deceased and the structure of the grave changed, and grave gifts disappeared. However, deviations are noticeable. According to Derek Welsby, the norms of Christian ritual were usually observed, but elements of local or family traditions are visible. Archeology provides us with many examples of care for the body of the deceased, who was wrapped in a shroud and his face often covered with material, sometimes embroidered $^{48}$. An interesting practice was to place prayer texts on the shroud, which are strongly associated with Ethiopian prayer over linen robes. Sets of grave texts from Ukma-West, Dongoli and Qasr Ibrim are also an important element for [studying] Nubian funeral practices. In three main inscriptions from a set of texts from Dongola, Our Lady occupies a central place. She had been a patron of a holy death since late antiquity and a role model for "Christian dying" 49 . This belief also among Christians in Nubia is expressed in particular in fragments of two Coptic texts about the Dormition of the Blessed Virgin Mary, one of which reproduces a prayer that Our Lady said in the face of death. The Mother of God is shown in them as praying and dying, as well as ascending together with her Son Jesus into heaven. At the textual level, the deceased joins the Mother of God to the extent that he is no longer visible ${ }^{50}$. This combination facilitated widespread devotion to Mary as a symbol of Christian dying and of effective prayer ${ }^{51}$, not only in the Nile Valley ${ }^{52}$.

${ }^{48}$ D.A.Welsby, Observations on graves of the medieval period in the SARS concession at the Fourth Cataract [in:] Aegyptus et Nubia Christiana. The Wtodzimierz Godlewski Jubilee Volume on the Occasion of his 70th Birthday, eds. A. Łajtar, A. Obłuski, I. Zych, Warsaw 2016, pp. 613-628.

${ }^{49}$ See B.E. Daley, "At the hour of our death": Mary's Dormition and Christian dying in late patristic and early Byzantine literature, "Dumbarton Oaks Papers" 55 (2001), pp. 71-89.

${ }^{50}$ A. Lajtar, J. van der Vliet, Empowering the Dead in Christian Nubia. The Texts from a Medieval Funerary Complex in Dongola, Warsaw 2017, p. 260.

${ }^{51}$ See: B.E. Daley, "At the hour of our death...". Mary's Dormition and Christian dying in late patristic and early Byzantine literature; T. de Bruyn, Greek amulets from Egypt invoking Mary as expressions of "lived religion", "Journal of the Canadian Society for Coptic Studies" 3-4 (2012), pp. 55-69.

${ }_{52}$ A. Łajtar, J. van der Vliet, Empowering the Dead in Christian Nubia. The Texts from a Medieval Funerary Complex in Dongola, pp. 260-264. 
In Nubia, epitaph texts were written in Greek and Coptic, while the local language was completely ignored. Most likely, there were no regulations regarding the choice of language, and its use was a consequence of personal tastes. The lack of epitaphs in Old Nubian may indicate that the Nubians gave these grave inscriptions apotropaic significance. Both Coptic and Greek influences can be observed in the funeral text formulas, but local, Nubian eschatological reflection can also be observed. Most significant for Christianity having taken root in the local culture is the pronoia formula, which is undoubtedly the most Nubian. Those who died in Christian Nubia were surrounded by prayer, which was often written on epitaphs. The most popular prayer in Nubia was a request to God that the deceased may rest in the bosom of the patriarchs Abraham, Isaac and Jacob, which appears in both Greek and Coptic texts. Other elements of the cult of the dead have also been authenticated which originated in pre-Christian tradition, but were accepted by the Church and subjected to the process of inculturation. Such practices included arranging elaborate meals on the deceased's grave, pouring liquids onto the grave, and lighting lanterns.

Above all, tokens of private devotion testify to the importance of faith in everyday life. Objects of this type enjoyed considerable popularity in the Christian world. They also reflected the rank and status of their owners. The largest group of these, in Nubia, are small pectoral crosses made of various materials, from wood to precious metals. There were also devotional objects in which appeared the Mother of God, angels, saints and biblical scenes. Unfortunately, these are very rare finds, but their existence indicates that there was a demand for such items. Their significance in the lives of Christians in Nubia, however, remains unresolved. It is impossible to determine by archaeological analysis whether their owners treated them as amulets, or if they identified with their essence.

\section{Indigenousness or extraneous nature of the Church in Nubia?}

The methods adopted in this study have made it possible, despite the fragmentation of data, to outline the situation of the Church in Nubia during the existence of Christian kingdoms from around 540 to 1500 , based primarily on archaeological and epigraphic sources derived from excavations carried out in Nubia. An analysis of these creates, as far as possible, an image of the relationship between Christianity and local culture, and provides guidelines for deriving reliable, critical and objective conclusions regarding the causes of the disappearance of Christianity in the Middle Nile Valley. The intercultural indicators of Christianity which were described in Nubia are a proposition for an informed and critical approach to the issues of the implementation of the basic missions of the Church in a given local culture - the mission to evangelize, and the testimony of actual experience of faith 
in Jesus Christ. In this respect, the Church there is often perceived by the paradigm of cultural colonialism, in which otherness is excluded and imposes cultural models on the designers and implementers of evangelization models and theology ${ }^{53}$. Marcy A. Oduyoye has even suggested that Christianity in Nubia in the period from the 6th to the 16th century was similar to colonial Christianity in Africa in the 1940-50 's. Foreign leadership assigned to this Church by the Patriarch of Egypt (Alexandria) and the importation and translation of books caused it to be dependent on outsiders ${ }^{54}$. This led, as the author notes, to a situation where the Church "starved" to death when Muslims managed to isolate Nubia from Egypt. The Nubian Church had no local resources upon which to rely. However, it is clear from the analysis carried out in this article that this image does not take the aspirations of the inhabitants of the Nile Valley into account at all, and reduces the factors that led to the fall of Christianity only to those issues related to lack of integration of Christianity with local culture, and this, as has been proved in this work, did take place. The reasons for the disappearance of Christianity in Nubia are therefore not so clear-cut.

Let us take a look at this Church, which emerges from the darkness of oblivion and the sands of the desert. It drew much from the traditions of the Christian East-Byzantium, Alexandria, and Syro-Palestine, but did not reproduce these measures slavishly. It was able to adapt and apply them to its needs. At the end of the Christian world, far in the south, various customs and practices of the Eastern Churches intersected, which, combined with local forms of expression, produced a strange but highly-developed Church. The local culture was just beginning to form and become distinct at the time of the official introduction of Christianity into the Nubian Kingdoms. The interaction between this culture and the new religion seems to be a process of creative dialogue; already in the first centuries after official Christianization there is evidence of its integration with local culture, the most prominent example of which is the literacy of the local language (which was certainly due to the local Church), and above all the translation of the Holy Scriptures into Old Nubian and the use of these translations in the Church's liturgy. It seems that faith in Jesus Christ was not a completely foreign element in Nubian culture, nor the liturgy a collection of incomprehensible rituals and words. The local culture demonstrated openness to faith in the Triune God before its official Christianization. Reception of the Faith allowed Nubia to benefit from the rich treasury of Christian oikumene.

This study points to a strong connection between the Church and the royal court. It was the beneficiary of property and benefited from favorable policies

${ }^{53}$ A. Pietrzak, Modele ewangelizacji kultur i inkulturacji wiary w teologii latynoamerykańskiej, p. 388 .

${ }^{54}$ M. Oduyoye, Hearing and Knowing: Theological Reflections on Christianity in Africa, Maryknoll 1986, p. 26. 
of the Nubian rulers. During the period of exceptional development of Makuria, monumental churches were created, richly decorated with paintings. The laity followed in the footsteps of the kings, demonstrating their attachment to the Church through funding and caring for numerous shrines. The Church strongly expressed its status through its monumentality and its closeness to the centers of power, at both the national and regional level. This relationship made the Church institution dependent on the economic and social well-being of the state. The economic crisis and unrest associated with power struggles in Makuria, and the threat of invasion by Muslim Egypt, caused the collapse of the Nubian kingdoms. It also resulted in the gradual disappearance of Church structures and hierarchy. The lack of help from the mother Patriarchate of Alexandria, and the Church in Nubia being left alone, was also of great importance in this matter. Although evidence suggests that churches were still used for Christian worship for some time, there was soon no one to celebrate the liturgy in them. There remained only groups of Christians left without priests to celebrate the sacraments, condemned to fall into the great sea of the Islam. Reports from the Portuguese from the 16th century indicate that Christians had survived in these areas until that time. Among the mentions of Christians who lived in Nubia after the fall of the Christian kingdoms, noteworthy is the letter of 1742 Father Giacomo Rzimarz da Cremsir to Cardinal Belluga, in which he speaks of Christians living in a village on the island of Tangos, probably Banganarti ${ }^{55}$.

The answer to the question as to why Allah appeared in place of the Triune God seems quite obvious. The disappearance of Christian worship caused a need for religiosity, because man is by nature homo religiosus. Islam as a religion had never been a serious threat to Nubians. As the Christian world fought bloody battles and experienced persecution by Muslims, Christian Makuria did the impossible. Not only did she win military clashes, but she also signed the baqt, which for centuries was a document normalizing relations with Egypt. And although these relations deteriorated significantly in the 13th and 14th centuries, Muslim persecution of the Christian population in Nubia has not been confirmed. The destruction of churches was caused by warfare. It also seems that apart from the cathedral in Qasr Ibrim, no other church has been turned into a mosque. Therefore, Islam was an alternative for Christians abandoned by their shepherds in Nubia. After all, this religion contained elements of the Christian faith: Jesus, Mary, archangels; and at the same time posed far fewer demands. The process of Islamizing Nubia took place most likely through mixed marriages. We have no evidence of coercion to adopt a new faith, which indicates that the reason for adopting Islam was the need to express one's religiosity in a particular religion

${ }^{55}$ B. Żurawski, St Raphael Church I at Banganarti mid-sixth to mid-eleventh century. An introduction to the site and the epoch, Gdańsk 2012, pp. 128-129. 
having worship, doctrine and law. For all that, Islam there had long been a combination of Christian and Muslim beliefs and old local cults. Perhaps the situation would have been different if Nubian Christians had experienced persecution by Muslims. The blood of the martyrs, the seed of the Church, did not flow in Nubia. Based on analysis we can conclude that the process of inculturation of the Church in Nubia, although it implemented the basics, did not run evenly. It certainly depended on the charisma and theological preparation of the local clergy and the commitment of the faithful. However, in light of the sources available to us, we can say little in this matter. Local administrative structures and the local clergy provided great inculturation opportunities. But the strong ethnocentrism of this Church must also be taken into account. The lack (or very weak presence) of evangelization activities to neighboring peoples caused a hermetic closure of the community of Nubian believers.

In the light of the above analysis, it can be assumed that Christians in Nubia remained in the faith as long as Christian worship existed. However, this perseverance in their faith was never associated with specific consequences of their choice, such as enduring persecution. But was an ability to bear witness to faith through every dimension of human life an effect of their faith? Faith in God's omnipotence was very deep in the Nubians. But it was carried out above all through magical amulets, signs, and texts that constituted a characteristic feature of Christianity there. They had a very distorted image of God, whom they probably understood as one more deity to protect them from demons and assure health and all other prosperity. Faith in the Triune God, revealed in Christ, was not a basis for further pursuit for Christians there. It seems that they may not have been able to establish a personal relationship with God revealed in the Son. Representations of Christ most often showed Him in full glory and divine majesty, never stressing His suffering. He was the Lord of the Universe, but not the One who suffered for the salvation of man. Yes, they believed in, or at least the Church there emphasized faith in, the Son's divinity, but there was no deeper relationship. God was as inaccessible to them as the Byzantine emperor, access to whom required the involvement of a number of intermediaries. That is why, the Mother of God, archangels, and saints held more significance in their devotion. The Nubians were convinced that it would be enough to direct requests to the appropriate intermediaries and they would pass them on to God. Such thinking resulted in God being for them someone distant, far from their usual everyday life. This delineation of theology in the local church meant that although Christianity was firmly rooted in local culture, it was not able to enter into relationships with concrete persons and show them the Revelation of the God who is not only the Lord of the Universe and the Conqueror of Hades, but also a Father for His children. When it came to making a choice, they were not capable of justifying their religious beliefs, because most likely, although they had persevered in the 
faith, the lack of personal relationship with God meant that they were unable to defend it.

\section{Summary}

This article is an attempt to define the relationship between Christianity in Nubia and the local cultures of the Nubian kingdoms of Nobadia and Makuria from the 6th to the beginning of the 16th century, using the inculturation criteria theory associated with the actualization of the Church within a particular culture in light of archaeological research.

The mission of the Church must be realized within a specific community of the people of God as well as in its administrative structure and the local hierarchy. The Church's task is to accomplish its sanctifying, prophetic and teaching mission, which is accomplished through the proclamation of the Gospel, the celebration of sacraments, funeral rites, and teaching of prayer practices. Due to lack of adequate resources, this Church's prophetic task was omitted. The Church, as archaeological research shows, also contributed to social life and the development of the material culture of the inhabitants of the Middle Nile Valley.

\section{Keywords}

Nubia, Church, Local Culture, Inculturation of Christianity, Nubian Kingdoms

\section{Zastosowanie kryteriów inkulturacji w badaniach nad rodzimością Kościoła w Nubii}

\section{Streszczenie}

Artykuł jest próbą określenia relacji między chrześcijaństwem a lokalną kulturą Nubii na podstawie analizy kultury nubijskich królestw Nobadii i Makurii. Wykorzystując teorię kryteriów inkulturacji, autorka przybliża sytuację Kościoła w Nubii w okresie od VI do początku XVI wieku, w świetle badań archeologicznych. Misja Kościoła musi być realizowana w określonej wspólnocie Ludu Bożego, a także w jego strukturze administracyjnej i lokalnej hierarchii. Zadaniem Kościoła jest wypełnianie jego misji uświęcającej, prorockiej i nauczycielskiej, które realizuje się poprzez głoszenie Ewangelii, sprawowanie sakramentów, obrzędów pogrzebowych i nauczanie praktyk modlitewnych. Ze względu na brak odpowiednich źródeł pominięto prorockie zadanie tego Kościoła. Kościół, jak pokazują badania archeologiczne, przyczynił się także do rozwoju życia społecznego i kultury materialnej mieszkańców Doliny Środkowego Nilu.

\section{Słowa kluczowe}

Nubia, Kościół, kultura lokalna, inkulturacja chrześcijaństwa, królestwa nubijskie 


\section{Bibliography}

Adams W.Y., Nubia: Corridor to Africa, Princeton 1977.

Adams W.Y., The United Kingdom of Makuria and Nobadia. A Medieval Anomaly [in:] Egypt and Africa. Nubian from Prehistory to Islam, ed. W. Davies, London 1991, pp. 257-263.

Araszczuk S., Język i formy pobożności ludowej, "Seminare. Poszukiwania naukowe" 20 (2004), pp. 163-179.

Azis A.S., History of Eastern Christianity, Notre Dame 1968.

Baczyński A., Zarys nauki o sakramentach w Kościele prawosławnym i rzymskokatolickim, „Elpis” 19 (2017), pp. 169-179.

Ballin C., The Christian community in Sudan in its Islamic context with special attention given to the era of the Mahdist Revelution (1881-1898), Roma 2007.

Bruyn de T., Greek amulets from Egypt invoking Mary as expressions of "lived religion", "Journal of the Canadian Society for Coptic Studies" 3-4 (2012), pp. 55-69.

Costalunga M., L'organizzazzione in province e regioni ecclesiastiche, "Iius Canonicus" 22 (1982), pp. 749-762.

Cuoq J., Islamisation de la Nubie chrétienne: VII ${ }^{e}$-XVI siècle, Paris 1986.

Daley B.E., "At the hour of our death". Mary's Dormition and Christian dying in late patristic and early Byzantine literature, "Dumbarton Oaks Papers" 55 (2001), pp. 71-89.

Dijkstra J.H.F., Philae and the End of Ancient Egyptian Religion. A Region Study of Religious Transformation (298-642 CE), Leuven 2008.

Drzewiecki M., Mighty Kingdoms and their Forts. The Role of Fortified Sites in the Fall of Meroe and Rise of Medieval Realms in Upper Nubia, Warsaw 2016.

Godlewski W., Pachoras. The Cathedrals of Aetios, Paulos and Petros. The Architecture, Warsaw 2006.

Gołgowski T., Liturgia nubijska i problem jej rekonstrukcji, „Saecullum Christianum” 14 (2007) 1, pp. 43-51.

Haberland E., Feste im Kirchenjahr des Christlichen Äthiopiens, "Zeitschrift für Kulturaustausch" 1 (1973), pp. 56-58.

Iliffe J., Africans: The History of a Continent, Cambridge 1995.

Łajtar A., A Late Christian Pilgrimage Centre in Nubia. The Evidence of Wall Inscriptions in the Upper Church at Banganarti, Leuven 2020.

Łajtar A., Późnochrześcijańska Nubia widziana przez pryzmat inskrypcji z Banganarti, „Studia Źródłoznawcze” 8 (2009), pp. 79-100.

Łajtar A., Literatura biblijna w Nubii chrześcijańskiej, „Scripta Biblica et Orientalia” 7-8 (2015-2016), pp. 123-144.

Łajtar A., Anna, the first Nubian Saint Know to us?, "Bulletin de la Société d'archéologie copte" 56 (2017), pp. 91-110.

Łajtar A., Vliet der van J., Rich Ladies of Meinarti and their Churches. With an appended list of sources from Christian Nubia containing the expression "having the Church of so-and-so", "The Journal of Juristic Papyrology” 28 (1998), pp. 35-53. 
Łajtar A., Vliet der van J., Empowering the Dead in Christian Nubia. The Texts from a Medieval Funerary Complex in Dongola, Warsaw 2017.

Luzbetak L., Kościól a kultury. Nowe perspektywy w antropologii misyjnej, trans. S. Tokarski. Warsaw 1998.

Mich K.A., Znaczenie świątyni chrześcijańskiej wśsietle osadnictwa w Makurii [in:] Sudan - archeologia i historia, eds. W. Cisło, J. Różański, M. Ząbek, Warsaw 2015, pp. 55-73.

Mich K.A., Problem zakorzenienia chrześcijaństwa w lokalnej kulturze Nubii a język liturgii Kościoła nubijskiego [in:] Sudan wojna, polityka, uchodźcy, eds. W. Cisło, J. Różański, M. Ząbek, Pelplin 2016, pp. 73-94.

Müller C.D.G., Grundzüge der Frommigkeit der nubische Kirche [in:] Études nubiennes. Colloque de Chantilly, 2-6 juillet 1975, eds. W.Y. Adams, P. Červíček, J. Leclant, Cairo 1978, pp. 209-224.

Obłuski A., The Monasteries and Monks of Nubia, trans. D. Dzierzbicka, Warsaw 2019.

Ochała G., The Nubian liturgical calendar. The evidence of the Nubian lectionaries, "Le Muséon" 128 (2015), pp. 1-48.

Oduyoye M., Hearing and Knowing: Theological Reflections on Christianity in Africa, Maryknoll 1986.

Pietrzak A., Modele ewangelizacji kultur i inkulturacji wiary w teologii latynoamerykańskiej, Lublin 2013.

Richter S.G., Studien zur Christianisierung Nubiens, Wiesbaden 2002.

Różański J., Inkulturacja Kościoła wśród ludów środkowego Sudanu, Poznań 2004.

Seignobos R., Les évêchés nubiens: nouveaux témoignages. La source de la liste de Vansleb et deux autres textes méconnus [in:] Nubian Voices II: New Texts and Studies on Christian Nubian Culture, eds. A. Łajtar, G. Ochała, J. van der Vliet, Warsaw 2015, pp. 151-229.

Shinnie P.L., Meroe: A Civilization of the Sudan. London 1967.

Török L., Late Antique Nubia: History and Archaeology of the Neighbour of Egypt in $4^{\text {th- }}$ $-6^{\text {th }}$ c. $A D$, Budapest 1988.

Welsby D.A., Medieval Kingdoms of Nubia. Pagans, Christians and Muslims along the Middle Nile, London 2002.

Welsby D.A., Observations on graves of the medieval period in the SARS concession at the Fourth Cataract [in:] Aegyptus et Nubia Christiana. The Wtodzimierz Godlewski Jubilee Volume on the Occasion of his 70th Birthday, eds. A. Lajtar, A. Obłuski, I. Zych, Warsaw 2016, pp. 613-628.

Werner R., Das Christentum in Nubien: Geschichte und Gestalt einer afrikanischen Kirche, Münster 2013.

Żurawski B., St Raphael Church I at Banganarti mid-sixth to mid-eleventh century. An introduction to the site and the epoch, Gdańsk 2012. 
Selected source about Christian archeological site from Nubia mentioned in this text

Adams W.Y., Meinarti II. The Early and Classic Christian Phases, London 2001.

Adams W.Y., Meinarti III: The Late and Terminal Christian Phases, London 2002.

Adams W.Y., Meinarti IV: The Church and the Cemetery. Meinarti; V: The History of Meinarti: an Interpretive Overview, London 2003.

Adams W.Y., Qasr Ibrim. The Earlier Medieval Period, London 2010.

Adams W.Y., Qasr Ibrîm. The Late Mediaeval Period, London 1996.

Aldsworth F., Qasr Ibrim. The Cathedral Church, London 2010.

Castiglione L. et al., Abdallah Nirqi 1964: The Hungarian Excavation in Egyptian Nubia, Budapest 1979.

Fouilles sur l'île de Saï (Soudan) 2005-2010, ed. D. Florence, D. Devauchelle, Lille 2011-2012.

Godlewski W., Tungul - archaeological guide, Warsaw 2013.

Michałowski K., Faras. Fouilles Polonaises 1961, Varsavie 1962.

Michałowski K., Faras. Fouilles Polonaises 1961-1962, Varsavie 1965.

Moorsel van P., Jacquet J., Diederik H., The Central Church at Abdallah Nirqi, Leiden 1975.

Obłuski A., Ochała G., La redécouverte d'un monastère nubien: premiers résultats des fouilles polonaises à Ouadi el-Ghazali [in:] Actes de la seizième Journée d'études coptes, Genève 19-21 juin 2013, eds. A. Boud'hors, C. Louis, Paris 2016, pp. 63-80.

Żurawski B., St Raphael Church II at Banganrti, mid-eleventh to mid-eigthteeth century, Warsaw 2014. 